\title{
Evaluation of ELectrolytes in Adult Patients with Acute Leukemia before and after Chemotherapy
}

\author{
Alea F. Salman*
}

\author{
Karima.F.Ali* \\ Received 18, March, 2012 \\ Accepted 10, July, 2012
}

Alaa.F.Alwan **

\begin{abstract}
:
Leukemia is a cancer of early blood forming cells. Most of them are cancers of white blood cells , however some leukemias start in other blood cell types.Electrolytes have modulatory effects on several biological mechanisms in the body namely as stabilizers,element of structures, essential element for hormonal function and also cofactors for a number of enzymes.In this study serum electrolytes levels were measured in patients with acute leukemia (AL) disorders before and after chemotherapy(anthracycline, doxorubicin, cytarabine ,prednisone, vincristine and doxorubicin) during one month and compared with that of control group. Blood samples were obtained from (43) patients (28 males and 15 females) aged (1555)years;juset before and after chemotherapy. The control group contained samples from (40) healthy volunteers (26 males and 14 females) aged (15-55) years.Serum electrolytes levels(sodium $\mathrm{Na}^{+1}$, potassium $\mathrm{K}^{+1}$, calcium $\mathrm{Ca}^{+1}$, chloride $\mathrm{Cl}^{-1}$, magnesium $\mathrm{Mg}^{+2}$ and phosphate $\mathrm{PO}_{4}{ }^{-3}$ ) were estimated using flame atomic absorbtion photometry. Serum levels of $\mathrm{Na}, \mathrm{K}, \mathrm{Ca}$ and $\mathrm{Cl}$ were significantly decreased in patients before chemotherapy in comparasion with that of control group. The mean concentration of serum phosphoruse and magnesium in acute leukemia patients was non significant compared with that of control group. In this study, determination of serum electrolytes in leukemic patients indicates an abnormal metabolic process in these patients.
\end{abstract}

Key words :acute leukemia, electrolyte abnormalities ,potassium ,sodium, calcium, magnesium,chloride and phosphate.

\section{Introduction:}

Acute leukaemia is a malignant disorder of white blood cells caused by a Failure of normal differentiation of haemopoietic stem cells and progenitors into mature cells. [1]. Most cases of acute leukemia (AL) can be classified as acute myeloid leukemia (AML) or acute lymphoid leukemia (ALL) using the French-AmericanBritish( FAB) and World Health Organization ( WHO) classification [2].Leukemia, like other cancers, results from somatic mutations in the DNA which activates oncogenes or deactivate tumor suppressor genes, and disrupt the regulation of cell death, differentiation or division. These mutations may occur spontaneously or as a result of exposure to radiation or carcinogenic substances and are likely to be influenced by genetic factors [3]. Acute leukemia is capable of altering the normal physiologic regulation of many systems,including serum levels of most electrolytes. Leukemia can alter the sreum electrolytes levels as a result of the disease process or drug therapy [4].A diverse groups of electrolytes abnormalities have been described in patients with acute leukemia [5].These disturbances are mainly considered to be associated with the leukemic process, organ

\footnotetext{
*Department of Chemistry, College of Sciences for Women,University of Baghdad,Iraq.

**National Center of Hematology/ Al-Mustansiriya University. 
infiltration, cell death and/ or therapeutic interventions [6] . Electrolyte and acid-base perturbations may be present regardless of the blast cell type [ acute myelogenous leukemia (AML) or acute lymphocytic leukemia (ALL)] or the state of the disease. These abnormalities present a potential hazard in patients with AL, as that of enhancing the cardiotoxic effects of certain chemotherapeutic regimens. In fact, fatal complications , such as sudden death due to malignant arrhythmias, have been reported in leukemic patients as an associated synergistic effect between antineoplastic drugs and electrolyte disorders[7]. Therefore,clinicians should be vigilant for early detection and appropriate management of electrolyte disturbances before the initiation of chemotherapy regimens as well as during treatment.Disorders of electrolytes are also frequently encountered in patients with malignant non-hematological disease, and may be present as metabolic emergencies [8,9] .The growing interest in electrolyte disorders induced by leukemia is mainly because prolonged survival with modern treatment allows these disturbances time to come to surface. Severe alterations in the serum electrolyte levels may be fatal in patients with potential chance of remission in leukemia [10].

\section{Materials and Methods:}

Tolal number of 43 patients were studied, 25 serum samples were from patients with acute myeloid leukemia, 18 patients with acute lymphoblastic leukemia(28male and 15 female).Rang of age was (15-55) years. Mean and standard deviation was $(37.07 \pm 14.88)$ on admission to the National center of Hematology/ALMustansiriya University and Baghdad Teaching Hospital - Medical department from November 2010 until the end of August 2011, regarding their serum electrolyte disturbances before and during their treatment.

All patient underwent,full supportive clinical examination such as transfusion of packed red cells, platelets and cryoprecipitate and they were treated according to their type of leukemia, and treatment options.Thirty-nine out of the fortythree patients had remission episodes within one month after treatment.Serum from 40 healthy volunteers was used as control (26male and 14 female),rang of age was(15-55).

Samples were collected from control subjects who are not receiving any medications,or pregnant, and did not have a history of any chronic or acute disease.About $3 \mathrm{ml}$ of venous blood was obtained from the cubital vein. In all cases blood samples were collected in the morning.

The blood samples were put in a clean dry plain plastic tube and were allowed to clot at $37{ }^{0} \mathrm{C}$ for $10-25$ minutes before centrifugation at 3000 rpm for 10- 15 minutes. The clear serum was transferred to clean plastic tubes by micro pipette.Serum electrolytes including sodium, potassium,calcium, magnesium,chlorid $\mathrm{e}$ and phosphate were measured by flame atomic absorbtion photometry.

Statistical analysis: the descriptive analysis was used to show the mean and standard deviation of variables. Student' $\mathrm{s}$ t-test was used and the probability $\mathrm{P}<0.05=$ significant, $\mathrm{P}>$ $0.05=$ non-significant

\section{Results and Discussion:}

Leukemia originates from hematopoietic stem cells that lose their ability to differentiate normally for production of the mature blood cell [11]. 
Table 1: The mean and standard deviation and the range of electrolytes in control and patients groups [before and after treatment] .

\begin{tabular}{|c|c|c|c|}
\hline Electrolyte & $\begin{array}{c}\text { Before treatment }(\mathrm{n}=43) \\
\text { mean } \pm \text { SD } \\
(\text { Rang })\end{array}$ & $\begin{array}{c}\text { After treatment }(\mathrm{n}=39) \\
\text { mean } \pm \mathrm{SD} \\
(\text { Rang })\end{array}$ & $\begin{array}{c}\text { Control }(n=40) \\
\text { mean } \pm \text { SD } \\
(\text { Rang })\end{array}$ \\
\hline $\begin{array}{l}\mathrm{Na}^{+}[\mathrm{mmol} / \mathrm{l}] \\
\mathrm{Rang}\end{array}$ & $\begin{array}{l}137.21 \pm 7.97^{\mathrm{a}, \mathrm{b}} \\
(103.0-149.0)\end{array}$ & $\begin{array}{l}142.35 \pm 5.96 \\
(131.0-158.0)\end{array}$ & $\begin{array}{l}140.55 \pm 2.59 \\
(136.0-144.0)\end{array}$ \\
\hline $\begin{array}{l}\mathrm{K}^{+} \quad[\mathrm{mmol} / \mathrm{l}] \\
\operatorname{Rang}\end{array}$ & $\begin{array}{l}3.92 \pm 0.76^{\mathrm{b}, \mathrm{c}} \\
(2.6-5.6)\end{array}$ & $\begin{array}{l}4.02 \pm 1.21^{\mathrm{c}} \\
(3.1-8.0)\end{array}$ & $\begin{array}{r}4.12 \pm 0.58 \\
(3.5-5.5)\end{array}$ \\
\hline $\begin{array}{l}\mathrm{Ca}^{+2}[\mathrm{mmol} / \mathrm{l}] \\
\mathrm{Rang}\end{array}$ & $\begin{array}{l}1.94 \pm 0.40^{\mathrm{a}, \mathrm{d}} \\
(1.0-2.9)\end{array}$ & $\begin{array}{r}2.13 \pm 0.44 \\
(1.1-2.9)\end{array}$ & $\begin{array}{c}2.25 \pm 0.14 \\
(2.1-2.5)\end{array}$ \\
\hline $\begin{array}{l}\mathrm{Cl}^{-1}[\mathrm{mmol} / \mathrm{l}] \\
\text { Rang }\end{array}$ & $\begin{array}{c}98.53 \pm 7.98^{c} \\
(70-120.0)\end{array}$ & $\begin{array}{c}100.35 \pm 5.96 \\
(83-110.0)\end{array}$ & $\begin{array}{c}101.40 \pm 2.42 \\
(98-107.0)\end{array}$ \\
\hline $\begin{array}{ll}\mathrm{Mg}^{+2} & {[\mathrm{mmol} / \mathrm{l}]} \\
\operatorname{Rang} & \end{array}$ & $\begin{array}{r}0.92 \pm 0.30 \\
(0.3-2.2)\end{array}$ & $\begin{array}{c}0.88 \pm 0.21 \\
(0.6-1.4)\end{array}$ & $\begin{array}{c}0.83 \pm 0.14 \\
(0.66-1.2)\end{array}$ \\
\hline $\begin{array}{l}\mathrm{PO}_{4}^{-3}[\mathrm{mmol} / \mathrm{l}] \\
\text { Rang }\end{array}$ & $\begin{array}{l}1.24 \pm 0.31 \\
(0.38-2.1)\end{array}$ & $\begin{array}{l}1.20 \pm 0.41 \\
(0.65-2.6)\end{array}$ & $\begin{array}{l}1.19 \pm 0.20 \\
(0.9-1.3)\end{array}$ \\
\hline
\end{tabular}

${ }^{\text {a }} \mathrm{P}<0.01$ compared with control group .

${ }^{\mathrm{b}} \mathrm{P}<0.01$ compared with the group after treatment .

${ }^{\mathrm{c}} \mathrm{P}<0.05$ compared with control group .

${ }^{\mathrm{d}} \mathrm{P}<0.05$ compared with the group after treatment.

Electrolyte abnormalities per se have not been yet nominated as one of the factors for predicting a worse outcome. Indirectly though, mucosal breach associated with cytotoxic chemotherapy has been suspected to be a cause of worse out comes in patients having cytopenia secondary to chemotherapy, compared to those who have neutropenia secondary to viral infections[12].

The mean and standard deviation of blood sodium and potassium after achieving remission were $142.35 \pm 5.96 \mathrm{mmol} / \mathrm{l}$ and $4.02 \pm 1.21 \mathrm{mmol} / 1$ respectively which showed significant increase in their concentration after chemotherapy $(\mathrm{P}<0.01)$, as shown in Table 1 . The mean and standard deviation of blood sodium and potassium before treatment were $137.21 \pm 7.97 \mathrm{mmol} / 1$ and $3.92 \pm 0.76 \mathrm{mmol} / \mathrm{l}$ respectively which show significant decrease between before and after treatment but didn't reach that of the control group
$(140.55 \pm 2.59 \mathrm{mmol} / \mathrm{l} \quad, \quad 4.12 \pm 0.58$ $\mathrm{mmol} / \mathrm{l}$ ) respectively as shown in Table 1.

Hyponatremia(decrease blood $\mathrm{Na}^{+}$level), a serious electrolyte disorder associated with lifethreatening neurological complications, is one of the most common electrolyte disorders associated with tumor-related conditions[13].Hyponatremia is proposed to be due to an inappropriate production of antidiuretic hormone (vasopressin) by the leukemic cells [14].It was well known that antineoplastic agents such as vincristine, vinblastine and cyclophosphamide induce hyponatremia in AL patients. The mechanism seems to be cytotoxicity affecting paraventricular and supraoptic neurons[15]. Hyperkalaemia (increase blood $\mathrm{K}^{+}$ level) results from initial lysis of tumour cells and then becomes exacerbated by the development of 
uraemia (renal failure) and this is occasionally secondary to excess iatrogenic administration of potassium during induction therapy. The rapid rise in serum potassium may result in severe arrhythmias and sudden death [16].

Some antileukemic drugs can cause hyperkaluria(increased $\mathrm{K}^{+1}$ level in urine) which suggest that the destruction of leukemic cells will release substances which are toxic to the kidney [17].

In the present study of 43 cases of acute leukemia, (24/43) patients $(55.8 \%)$ had hypocalcemia (decrease blood $\mathrm{Ca}^{+2}$ level) (serum $\mathrm{Ca}^{+2}<$ $2.1 \mathrm{mmol} / \mathrm{l}$ ). When compared with that of control, patients had a significantly $[\mathrm{P}<0.01]$ lower value of $\mathrm{Ca}^{+2}(2.25 \pm 0.14 ; 1.94 \pm 0.40 \mathrm{mmol} / \mathrm{l})$ respectively.

Hypocalcemia is commonly seen in leukemia[18] .A retrospective study in patients with acute leukemia indicated that $1 / 3$ of the patients had constant, and almost half had intermittent

hypocalcemia[19].Leukemias can also lead to hypocalcemia particularly during chemotherapy treatment which causing tumour lysis syndrome.Also hypocalcemia may occur due to therapeutic interventions in these malignancies[20]. In present study, the incidence of hypercalcemia in AL after chemotherapy was about (16.6\%). Our results showed no statistical differance between patients after achieving remission and control,but before and after treatment there were statistical significant

$(2.13 \pm 0.44$

$2.25 \pm 0.14 \mathrm{mmol} / \mathrm{l}$ respectively, p> $0.05) \quad(1.94 \pm 0.40 ; 2.13 \pm 0.44 \mathrm{mmol} / \mathrm{l}$ respectively,p<0.03) Table 1.

Serum chloride levels in patients before treatment showed significant $[\mathrm{P}<0.05]$ decrease when compared with that of control group $(98.53 \pm 7.98 ; \quad 101.40 \pm 2.42 \mathrm{mmol} / \mathrm{l}$, respectively), while there was no significant $[\mathrm{P}>0.05] \quad$ difference between patients after achieving remission and control group $(100.35 \pm 5.96 ; \quad 101.40 \pm 2.42 \mathrm{mmol} / \mathrm{l}$ respectively) as shown in Table 1 .

Chloride is normally lost in the urine, sweat, and stomach secretions. Hypochloremia(decrease blood $\mathrm{Cl}^{-1}$ ) can occur from excessive loss during heavy sweating, vomiting, diarrhea, adrenal gland and kidney disease,hypochloremic alkalosis,hypovolemia, and psychomotor disturbances[21]. However, 10 to $20 \%$ of tumors will secrete chloride [22].

Serum phosphate levels show non significant $[\mathrm{P}>0.05]$ difference between patients (before and after treatment) as compared with that of control group $(1.24 \pm 0.31 ; 1.20 \pm 0.41$; $1.19 \pm 0.20 \mathrm{mmol} / \mathrm{l}$ respectively $\mathrm{P}>$ $0.05)$ as shown in Table 1.

Hypophosphatemia( decrease blood $\mathrm{PO}_{4}{ }^{3-}$ ) described in acute leukemia patients, has been occasionally ascribed to a decreased $\left(\mathrm{PO}_{4}{ }^{3-}\right)$ cell's intake, but the leading causes are either a shift of $\left(\mathrm{PO}_{4}{ }^{3-}\right)$ ions into rapidly growing tumor cells or inappropriate urinary loss [23]. Hyperphosphataemia results from the rapid release of intracellular phosphorous from malignant cells, which may contain as much as four times the amount of organic and inorganic phosphorous as compared to normal cells [16].

According to the present study our results showed that serum magnesium level in acute leukemia patients show non significant $[\mathrm{P}>0.05]$ difference before and after treatment, as well as, when compared to the outcome before treatment and control and after achieving clinical remission and control $(0.92 \pm 0.30 ; \quad 0.88 \pm 0.21$; $0.83 \pm 0.14 \mathrm{mmol} / 1$ respectively ) as shown in Table 1. 
Hypomagnesemia(low $\mathrm{Mg}^{+2}$ blood level ) has been identified in cancer patients long after the drug treatment has been stopped. This type of hypomagnesemia is caused by cisplatin-induced renal tubular defect in $\mathrm{Mg}$ reabsorption[24].

\section{Conclusions:}

Electrolytes imbalance is a common finding in acute leukemia.The alteration in electrolyte concentration brought on by the leukemic process per se or by the therapeutic regime may be life threatening. This study emphasizes the need for routine measurement of serum electrolytes during all phases of the leukemic process.

\section{References:}

1. Drew Provan. ABC of clinical haematology.: In acute leukemia $.3{ }^{\text {rd }}$ ed.Black weli Publishing LTd. London UK;2007. P 27-30.

2. Xiao-Qian Xu, Wang J-M and XiaoQiaXu.,2009.Clinical and biological characteristics of adult biphenotypic acute leukemia in comparison with that of acute myeloid leukemia and acute lymphoblastic leukemia: a case series of a Chinese population .Haematologica 94:919-927.

3. Stass SA, Schumacher H R, and William R.2000. "Handbook of hematologic pathology". New York, N.Y: Marcel Dekker. pp. 193-194.

4. Sean o' Regan, Stephen Carsoh, Russell W. Chesney, et al.,1977. Electrolyte and acid-base disturbances in the management of leukemia, Blood.,49:345-353.

5. Olgar S, Yetgin S, Cetin M, Aras T, and Akhan O.,2005.Electrolye abnomalities at diagnosis of acute lymphocytic leukemia may be a clue for renal damage in long-term period . J Pediatr Hematol Oncol .,27(4):202-206.

6. Theodosios D. Filippatos, Haralampos J. Milionis, et al,.2005 .Alterations in electrolyte equilibrium in patients with acute leukemia. Eur J Haematol $., 75: 449-460$

7. Westervelt $\mathrm{P}$, Browen RA, Adkins DR, Khoury $H$, Curtin P, Hurd D, Luger SM, $M_{A}$ MK, Ley TJ, DIP-ersio JF.,2001.Sudden death among patients with acute promyelocytic leukemia treated with arsenic trioxide. Blood., 98:266-271.

8.Lafrance JP, and Leblanc M.,2005. Metabolic electrolytes and nutritional concerns in critical illness. Crit Care Clin., 21: 305-327.

9. Gunnerson KJ, and Kellum JA.,2003. Acid-base and electrolyte analysis in critically ill patients: are we ready for the new millennium Curr Opin Crit Care., 9: 468-473.

10.Orten LM, and Neuhaus OW.1982 . "Human Biochemistry", 10 th edition, the C.V. Mosby Company.St louis. PP 729-732,.

11. Vanessa B., Liési D.K. Madersa, Margarete D. Bagatinia, Karen F. Santosa, Rosélia M. Spanevellob, Paula A. Maldonadoa and Alice O. Bruléc, Maria do Carmo Araújoc, Maria R.C. Schetingera, andVera M. Morsch,2008.Measurement of oxidative stress and antioxidant status in acute lymphoblastic leukemia patients Clin. Biochem.,.41, 7,

12. Asim Jamal Shaikh, Bawany SA, Masood N,Khan AA, Abbas AN and Salman Adil , . 2011. Incidence and impact of baseline electrolyte abnormalities in patients admitted with chemotherapy induced febrile neutropenia . J. of Cancer. 2:62-66

13.Wakui A.,1986. Electrolyte abnormalities associated with cancer: a review. Gan To Kagaku Ryoho 13:2031-2038.

14 . Udayakumar N, Rajendiran C, Muthuselvan R.,2006.A typical presentation of acute myeloid leukemia. J Cancer Res Ther 2: 8284. 
15. Enas M.K.,2001.Erythrocyte glutathione, serum electrolytes and trace elements levels in childhood acute lymphoblastic leukemia. M.Sc .Thesis. Collage of medicine, AlMustansiriyah University.

16. Mitchell S. Cairo and Michael B.2004.Tumour lysis syndrome: new therapeutic strategies and classification. Blackwell Publishing Ltd, British J. Haemato. 127: 3-11.

17. Dargie HJ, Boddy K, Kennedy AC, King PC, Read PR, and Ward DM.1974. Total body potassium in long-term frusemide therapy: is potassium supplementation necessary,Br Med J. 4:316-319.

18.Mc Kee Lc Lr.,1993. Hypocalcemia in leukemia. Southern Med J., 68: 828832.

19. Romeril-KR., Concannon-AJ, and Biggs-LC.,1998. Metabolic abnormalities in adult ALL N-Z-Med-J . 94:299-301.

20. Rubina M. , Farooq A. K,.2010. Frequency of Occurrence of Hypocalcemia in Various Disorders. Ann. Pak. Inst. Med. Sci., 6(1): 44-49.

21. RajuSM,BinduR. "IIIustrated Medical Biochemistry". $2^{\text {nd }}$ ed.,SMRaju,Bindu; 2010. p 162.India.

22.JohNnh. Gall.,2000 . Metabolic Alkalosis. J Am Soc Nephrol 11: 369-375.

23. Meindert J. Crop, Ewout J. Hoorn ,Jan Lindemans and Robert Zietse 2007.Hypokalaemia and subsequent hyperkalaemia in hospitalized patients.Nephrol Dial Transplant. 22: 3471-3477.

24. Lajer H, Daugaard G.,1999. Cisplatin and hypomagnesemia. Cancer Treat Rev .,25:47-58.

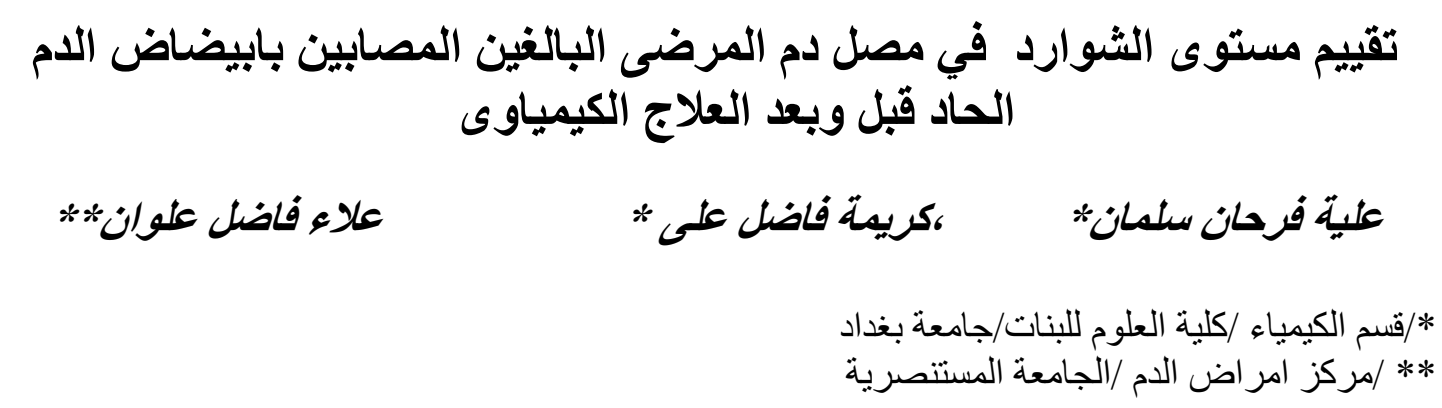

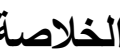

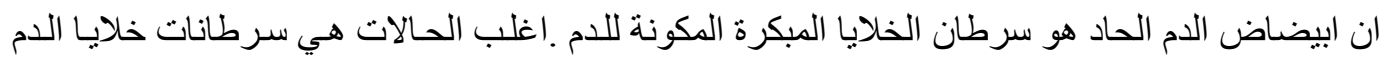

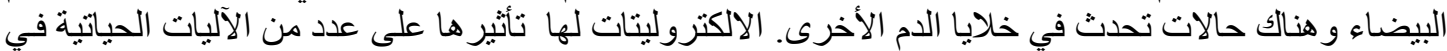

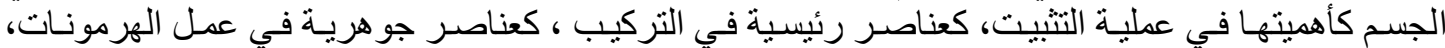

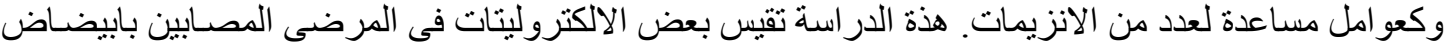

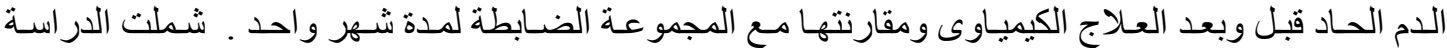

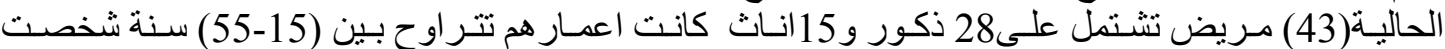

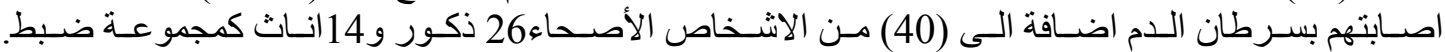

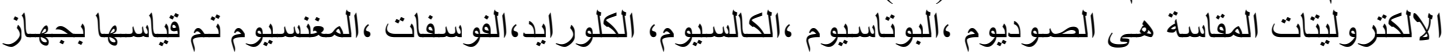

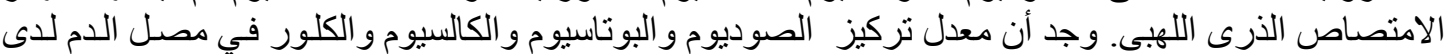

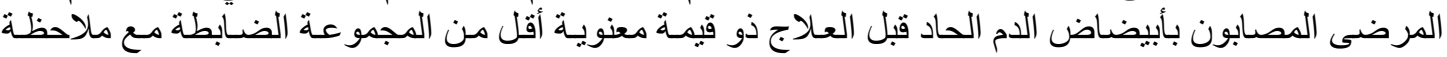

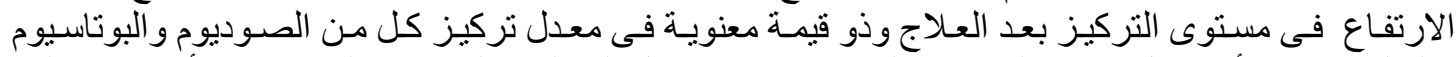

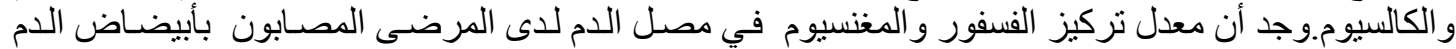

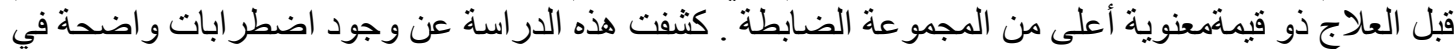

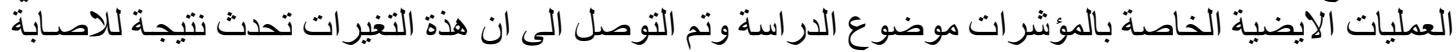


